\title{
Analysis of Pattern Rice Businesses Legoo Crops 2:1 and Tegelin District Moncongloe, Maros Regency
}

\author{
Muhamad Ilham ${ }^{1}$, Yunus Musa², A. Nixia Tenriawaru ${ }^{3}$ \\ ${ }^{1}$ Agribusiness Study Program at Postgraduate, Hasanuddin University \\ ${ }^{2}$ Departement of Agricultural Agro-Technology, Faculty of Agriculture, Hasanuddin \\ University \\ ${ }^{3}$ Department of Agricultural Socio-Economics, Faculty of Agriculture, Hasanuddin University \\ ${ }^{*}$ Corresponding author: \\ Email: ilham.densus87@gmail.com

\begin{abstract}
.
This study aims to analyze the productivity and income of farmers on the pattern row planting legowo and tiles as well as formulate alternative strategies that are appropriate for the development of paddy rice rain-fed in an effort to increase productivity and income of farmers in the District Moncongloe Maros Regency of South Sulawesi. The research method used is purposive sampling based on the type of rice varieties used, namely Inpari 33 with the pattern of row planting legowo and tiles as well as rainfed land. The sample taken is a member of the farmer group Biring Jene 1 and farmer group Biring Jene 2. Two of these groups are selected because members of this group there that uses the pattern legowo row planting and using varieties Inpari 33. The results of the research that the amount of revenue jajar legowo higher compared to tiles with at $9.358,3 \mathrm{~kg} / \mathrm{Ha}$ or Rp. 42.112 .350 to forecast legowo row planting and 4.185,4 $\mathrm{kg} / \mathrm{Ha}$ or $\mathrm{Rp}$. 18.834.449 for the reception of grain production in the cropping pattern tiles, with a difference of the receipt of such production of $5.172,9 \mathrm{~kg} / \mathrm{Ha}$ or $\mathrm{Rp}$. 23.277.901 and the value of the $R / C$ ratio of 1,53 jajar legowo and of 1.49 for the tiles. The formulation of the strategy of SWOT analysis is a Strategy S-O, among others, the Development and improve the human resource capabilities of farmers in agricultural technology innovation, strategy $W$-O, among others, improve the ability mastery of appropriate technology for farmers, the strategy $S-T$, among others, the optimization of the agricultural land and the strategy of $W$-T, among others, use varieties that are resistant to PEST and disease and able to survive extreme conditions.
\end{abstract}

Keywords:jajar legowo, tiles, reception farm, $R / C$ ratio, the $S W O T$.

\section{INTRODUCTION}

According to data from the Central Statistics Agency (BPS) for 2018, the total population of Indonesia reaches approximately 265 million people and the amount of rice production in Indonesia reaches around 56.54 million tons of Milled Dry Unhulled (GKG). In cultivating lowland rice, farmers in Moncongloe District generally use the tile cropping system and the scattering system, however, some farmers use the legowo row cropping system. The factors that cause farmers to still maintain the tile and scattered systems are because it is easier and does not require too much labor, cost, and time. In the application of the row cropping pattern application to farmers in the District of Moncongloe Legowo, there are still obstacles such as the legowo row cropping pattern requiring more labor so that it will require more time and money so that farmers find it difficult to accept this legowo row system and prefer to use the 
conventional system. From generation to generation, local extension workers have provided various information about the latest technology, one of which is the legowo row cropping pattern which is proven to be able to increase production. Agriculture is defined as an activity that involves the production process to produce materials that human needs can come from plants and animals, accompanied by efforts to renew, reproduce (reproduce) and consider economic factors [1]. According to Wanda in Saeri that farming science is a science that studies how to determine, organize and coordinate the use of resources effectively and efficiently so that the income earned by farmers is higher [2]. Farming classification is formed due to differences in several factors in agricultural activities, first, namely physical factors consisting of geographic and topographic location of a land, climatic conditions and soil types that can cause differences in the crops that can be planted by farmers. Second, the economic factor which consists of costs, capital owned by farmers, market supply, market demand, and risks faced. So that the economic factor will provide a limit to farmers in doing farming. The third is other factors consisting of social conditions, plant pests and diseases, and others which can also hinder farming activities carried out by farmers. According to Luthfiyah, labor in farming activities includes the characteristics of labor in farming and family labor and outside the family

The principle of the legowo row cropping pattern is to increase the plant population by adjusting the spacing so that the plantations will have rows of plants interspersed with empty rows where the spacing on the margins is half the spacing between rows. The legowo row cropping system is a step to manipulate the crop so that the crop can have a greater number of fringe plants. It is known that rice plants located at the periphery have better growth and development than those in the middle row, thus providing higher grain yield and quality. This is because plants that are on the edge will get more sunlight intensity (edge crop effect). Based on the results of research by Abdulrahman, S., et al., That the 2: 1 legowo row pattern cropping with a spacing $(25 \times 12.5 \times 50) \mathrm{cm}$ was able to increase the yield between $9.63-15.44 \%$ compared to the tile model [3]. The number of tillers/clumps and the number of panicles/clumps are components that support the increase in yield. The results of the study conducted by Aji., Et al. In Jember Regency, East Java Province, indicated that it is necessary to utilize strategic factors that have a major strength and their importance is relatively high [4].This study aims to analyze the productivity and income of farmers in the cropping patterns of legowo and tiles and formulate suitable alternative strategies for the development of rainfed lowland rice commodities in an effort to increase farmers' productivity and income in Moncongloe District, Maros Regency, South Sulawesi.

\section{METHODS}

The research was conducted in Moncongloe District, Maros Regency, South Sulawesi. The type of data used is primary data obtained through direct observation and interviews, either structured or semi-structured, with respondents, namely rice 
farmers, using a questionnaire guide. Interviews were conducted with the aim of knowing a general description of the current business conditions. Secondary data were obtained from various related sources such as Village Offices, District Offices, Extension Centers, and Services related to this research. The method used is purposive sampling because every element in the population has an equal chance of being selected. The total population of farmers is 1410 . With this population, the sample used in accordance with the objectives of the researcher is 6 people divided by 3 people using the legowo row cropping pattern with the Inpari 33 variety and 3 people using the tile cropping pattern with the Inpari 33 variety. This group is a member of the Bring Jene 1 farmer group and the Biring Jene 2 farmer group. These two groups were selected because some members of this group use the legowo row cropping pattern and use the Inpari 33 variety.

Analysis of the 2: 1 legowo row and tile farming pattern in Moncongloe subdistrict, Maros district uses a tool, namely SWOT analysis, which systematically identifies various factors to formulate a company strategy, [5]. According to Rangkuti [6], SWOT analysis is a systematic identification of various factors to formulate a company strategy. SWOT analysis has good and profound implications for successful designs and strategies, Sedarmayanti [7]. The result of the SWOT analysis is the identification of the company's distinctive competencies derived from the company's internal resources and capabilities as well as a number of opportunities that have not been exploited by the company, for example, due to the company's internal deficiencies and capabilities. The SWOT analysis approach as developed by Kearns features eight boxes. The top two boxes are external factors (opportunities and threats) while the two boxes on the left are internal factors (strengths and challenges). The other four boxes are cities for discussion of strategies that emerge as a result of the intersection of internal and external factors. Matrically it can be described as follows;

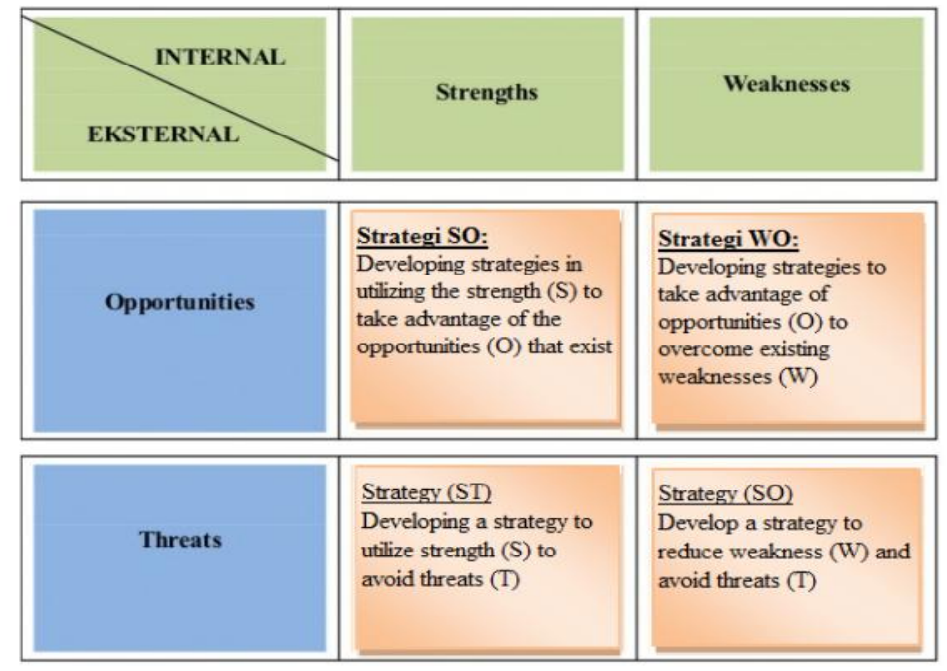

Fig.1 Matriks SWOT 


\section{RESULT AND DISCUSSION}

The irrigation/irrigation of agricultural rice fields in Moncongloe District is divided into 2 irrigation systems, namely semi-technical and rainfed systems. The area of rice fields with semi-technical irrigation is 347.88 hectares and rainfed rice fields are 831.11 hectares. Paddy farming with legowo row and tile cropping patterns is the same, whether it is farming on rainfed lowlands or paddy fields with technical or semitechnical irrigation. The difference is in a large number of labor and seeds used in the legowo row cropping pattern. The fertilizer used in the legowo row planting system is more compared to the fertilizer used in the tile planting system, the types of fertilizers used in the legowo row planting system are more diverse, such as organic fertilizer, urea fertilizer, sp 36 fertilizer, NPK, and manure. Meanwhile, the tile farming system does not use manure, and less organic fertilizers are used compared to the legowo row system rice farming [8].

\section{Income and Cost Analysis}

In the legowo row cropping pattern, the seed required by the farmer is Rp. 415,000 , - more than the tile or urban cropping pattern at a cost of Rp. 340.000, Sowing the seeds is done by sowing in a tray or basin and sowing in the prepared paddy fields. Rice field processing is carried out using a rice plow tractor machine. Farmers who rent this tractor machine are charged Rp. 10,000 / are and is used for fuel costs and operational personnel. The cost of cultivating paddy fields for the legowo row cropping pattern and the tile cropping pattern with an area of 1 hectare is Rp. $1,000,000$.

In this legowo row type 2: 1 cropping pattern uses a spacing of $25 \mathrm{~cm} \times 12.5 \mathrm{~cm}$ (between edge rows) $x 50 \mathrm{~cm}$ for empty rows. Meanwhile, the tile cropping pattern uses a spacing of $25 \mathrm{~cm} \times 25 \mathrm{~cm}$. The planting pattern of legowo tiles and rows with a land area of $1 \mathrm{~m} 2$ can be seen in the image below;

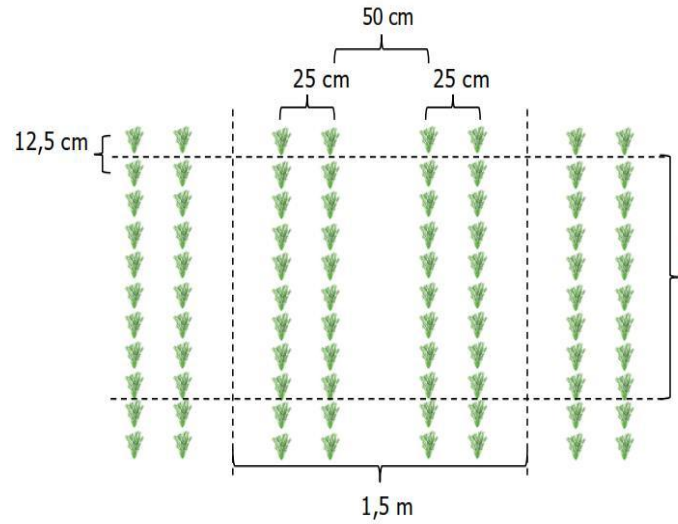

Legowo row planting pattern $2: 1$ spacing $25 \mathrm{~cm}$

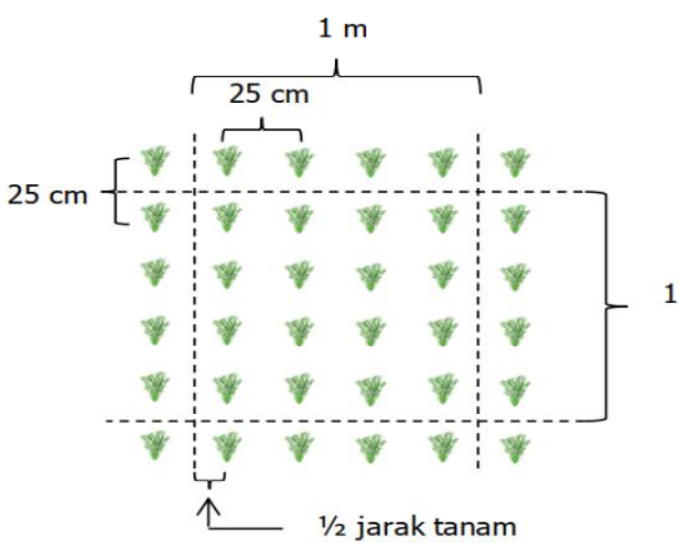

Planting pattern Tiles / tuber spacing $25 \mathrm{~cm}$

Fig.2. Planting patterns of tiles and rows of legowo with a land area of $1 \mathrm{~m} 2$

http://ijstm.inarah.co.id 
The costs incurred in making planting lines for the legowo row cropping pattern are Rp. 560,000, - / Ha and for the tile cropping pattern the cost of making rowing is Rp. $400,000,-/ \mathrm{Ha}$. The greater the costs incurred by the legowo row cropping pattern due to the slight complexity in making these cropping rows. For planting rice seedlings, whether it is a 2: 1 legowo row system or a tile pattern, the respondents gave around 35 rice seeds per 1 hole. The fee for this activity is Rp. 1,040,000 for the row cropping pattern and Rp. 480,000 for the tile cropping pattern. The difference in the amount of this cost is due to the fact that there are more workers in the tile cropping pattern than in the tile cropping pattern. This is in accordance with previous research on legowo rows (Abdulrachman, S., et al. 2013) that rice planting using the legowo row cropping pattern takes longer because the spacing is not symmetrical and some parts are left blank. This condition results in the need for more concentration for planting labor and higher costs for planting compared to the tile system.

The cost of maintaining the legowo row cropping pattern is Rp. 1,920,000, - and the tile cropping pattern costs Rp. 560,000, -. The amount of labor for maintenance costs in this legowo row is more due to the fact that the rows in the cropping pattern are a little tight and asymmetrical so that more intensive maintenance of the tile pattern is needed so that more workers are needed for effective handling during maintenance.

Harvest costs incurred by farmers in the form of manual harvest wages of Rp. 4,211,235 / Ha for harvesting legowo row cropping patterns and Rp. 1,883,500 / Ha for the tile cropping pattern. The second is the wage for transporting the crops from the fields to the house, the wages for transporting the harvested grain of Rp. 10,000 / sack, the wages paid by the farmers in transporting these crops are Rp. 2,406,420 for the cost of transporting the harvested legpwp row cropping patterns and Rp. 1,076,200 for the transportation costs of the tile planting pattern. The third is the wage for unhulled mills worth Rp. 2,751,840 for the milled yield of the legowo row cropping pattern and the amount of Rp. 1,250,754 for the tile cropping pattern.

Other costs in producing rice are a land tax for the legowo row cropping pattern with an area of 1 hectare. The tax paid is Rp. 269,656 and the land tax value for the tile cropping pattern with an area of 1 hectare of Rp. 454,230 depending on the value, area, and location of the land itself. Second, the cost of renting land between owners and tenants is done by sharing agricultural produce with a 50:50 agreement accompanied by a 50:50 distribution for the cost of purchasing fertilizers during the farming process during the planting season. The landowner will get half of the farm's yield in the form of wet grain after the rice has arrived at the farmer's warehouse. With this provision, the landowner will receive a land lease of Rp. 7,598,896 for planting legowo row and for renting the tile cropping pattern, the yield is Rp. 2,913,333.

The equipment often used by respondent farmers in farming in Moncongloe Subdistrict, Maros Regency, South Sulawesi, mostly uses tools in the form of hoes and sickles. Both of these tools are commonly used to map or tidy up rice fields. Hand 
sprayer is used when dealing with pests in rice plants. Whereas other equipment such as plow tractors for rice fields, rice thresher machines, and transportation equipment for transporting produce, farmers do not own them individually because activities that use these tools are carried out with a piece-rate system of profit sharing and are included in the group of workers outside the family.

The use of farm production costs for legowo row and tile cropping patterns in an area of 1 hectare can be seen in the following table;

Table 1. Use of production costs for rowing legowo and tile farming patterns on an area of 1 hectare

\begin{tabular}{clccc}
\hline \multirow{2}{*}{ No } & \multirow{2}{*}{ Item } & \multirow{2}{*}{ Unit } & \multicolumn{2}{c}{ Cropping Pattern } \\
& & Jajar Legowo & Tiles \\
\hline \multirow{2}{*}{ SMeans and production } & $\mathrm{Rp}$ & 4.161 .500 & 2.555 .000 \\
2 & Labor & $\mathrm{Rp}$ & 22.528 .391 & 8.723 .732 \\
3 & Depreciation of Equipment & $\mathrm{Rp}$ & 372.587 & 663.000 \\
\hline \multicolumn{2}{c}{ TOTAL } & & $\mathbf{2 7 . 0 6 2 . 4 7 8}$ & $\mathbf{1 1 . 9 4 1 . 7 3 2}$ \\
\hline
\end{tabular}

Meanwhile, the tools and equipment used by farmers in rice cultivation with legowo row and tile cropping patterns can be seen in the following table;

Table.2 Equipment and equipment used by farmers in cultivating rice with legowo row and tile cropping patterns

\begin{tabular}{llcccc}
\hline & & \multicolumn{4}{c}{ Cropping Pattern } \\
\cline { 3 - 6 } No & Tool's name & \multicolumn{2}{c}{ Jajar Legowo } & \multicolumn{2}{c}{ Tiles } \\
\cline { 3 - 6 } & & unit / Ha & Depreciation & unit/Ha & Depreciation \\
\hline 1 & Hoe & 6 & 38862 & 6 & 60000 \\
2 & Sickle & 5 & 29719 & 6 & 55000 \\
3 & Hand & 3 & 174002 & 3 & 356000 \\
& Sprayer & 5 & 130004 & 6 & 192000 \\
\hline & Tarpaulin & 5 & $\mathbf{3 7 2 5 8 7}$ & $\mathbf{2 1}$ & $\mathbf{6 6 3 0 0 0}$ \\
\hline
\end{tabular}

The acceptance of rice farming in Mocongloe District can be seen in the following table;

Tabel 3. Acceptance of rice farming in Mocongloe District

ACCEPTANCE OF RICE FARMING LEGOWO AND TEGEL CROP PLANTING PATTERNS IN 1 HECTAR

\begin{tabular}{|c|c|c|c|c|}
\hline \multirow{3}{*}{$\begin{array}{l}\mathbf{N} \\
\text { o }\end{array}$} & \multirow{3}{*}{ Item } & \multirow{3}{*}{ Unit } & \multicolumn{2}{|c|}{ Cropping Pattern } \\
\hline & & & Jajar Legowo & Tegel/Ubinan \\
\hline & & & Score & Score \\
\hline 1 & Number of production & $\mathrm{Kg}$ & $9.358,3$ & $4.185,43$ \\
\hline 2 & Price & $\mathrm{Rp} / \mathrm{kg}$ & 4.500 & 4.500 \\
\hline
\end{tabular}




\begin{tabular}{llccc}
3 & Number of admissions & $\mathrm{Rp}$ & 42.112 .350 & 18.834 .449 \\
4 & Total Cost & $\mathrm{Rp}$ & $30.532 .134,75$ & $13.995 .963,82$ \\
& $-\quad$ Cash costs & $\mathrm{Rp}$ & $26.959 .547,75$ & $11.732 .963,82$ \\
& - Fees are not cash & $\mathrm{Rp}$ & 3.572 .587 & 2.263 .000 \\
5 & Revenue & $\mathrm{Rp}$ & $15.152 .802,25$ & $7.101 .485,619$ \\
6 & Advantage & $\mathrm{Rp}$ & $11.580 .215,25$ & $4.838 .485,619$ \\
7 & $-\quad \mathrm{R} / \mathrm{C}$ ratio to total cost & & 1,53 & 1,49 \\
& $-\quad$ R/Cratioover cash expenses & & 1,74 & 1,78 \\
\hline
\end{tabular}

\section{Farm feasibility analysis using SWOT analysis tool}

a. Matrix Internal and External Strategic Factors Analysis Summary

These internal factors are structured to formulate internal strategic factors in the framework of strengths and weaknesses ( $\mathrm{S}$ and $\mathrm{W}$ ). Where this factor is related to the conditions that occur in rice farming in Moncongloe District, which also affects the formation of farmer decision making (decision making) in farming.

Table 4. Internal And External Factors In Farming

External Factors

\begin{tabular}{|l|l|}
\hline \multicolumn{1}{|c|}{ Strenght } & \multicolumn{1}{c|}{ Weakness } \\
\hline $\begin{array}{l}\text { Farmers know that the yield of legowo row } \\
\text { cropping patterns is high }\end{array}$ & $\begin{array}{l}\text { Requires a lot of seeds and a longer time to } \\
\text { plant }\end{array}$ \\
\hline Using superior variety seeds & $\begin{array}{l}\text { The irrigation channel has not yet reached the } \\
\text { farm }\end{array}$ \\
\hline Use of advanced technology & Limited access to capital for farmers \\
\hline $\begin{array}{l}\text { Average farming experience is over 10 } \\
\text { years }\end{array}$ & Lack of awareness of using manure \\
\hline Active farmer institution & Lack of manpower \\
\hline
\end{tabular}

Faktor Eksternal

\begin{tabular}{|l|l|}
\hline \multicolumn{1}{|c|}{ Peluang (Opportunities) } & \multicolumn{1}{c|}{ Ancaman (threats) } \\
\hline Availability of technological innovation & Change of land function \\
\hline There are business partners & Erratic climate \\
\hline There are agricultural extension officers & OPT attack \\
\hline Strong government policy & Land fertility is decreasing \\
\hline
\end{tabular}

b. The Internal and External Strategic Factors Analysis Summary below, with an average score of 3.098, it means that internally the strength value for increasing farming with lowland rice commodities in Moncongloe District is greater than weakness but is still in the weak category, whereas for the weakness factor included in the middle class. 
Table 5. Value Internal Strategic Factors Analysis Summary

Internal Strategy Factors $\quad$ Weight $\quad$ Rating $\begin{gathered}\text { Results of } \\ \text { Weight X } \\ \text { Rating }\end{gathered}$

\begin{tabular}{|c|c|c|c|}
\hline \multicolumn{4}{|l|}{$\begin{array}{r}\text { STRENGTH } \\
\end{array}$} \\
\hline $\begin{array}{l}\text { Farmers know that the yield of legowo row cropping } \\
\text { patterns is high }\end{array}$ & 0,11 & 3,83 & 0,42 \\
\hline Using superior variety seeds & 0,1 & 3,33 & 0,33 \\
\hline Use of advanced technology & 0,12 & 3,5 & 0,42 \\
\hline Average farming experience is over 10 years & 0,12 & 3,33 & 0,4 \\
\hline Active farmer institution & 0,1 & 2,83 & 0,28 \\
\hline \multicolumn{4}{|l|}{ WEAKENESSES } \\
\hline Requires a lot of seeds and a longer time to plant & 0,09 & 3,33 & 0,3 \\
\hline The irrigation channel has not yet reached the farm & 0,1 & 2,5 & 0,25 \\
\hline Limited access to capital for farmers & 0,08 & 1,83 & 0,14 \\
\hline Lack of awareness of using manure & 0,09 & 2,67 & 0,24 \\
\hline Lack of manpower & 0,09 & 3,83 & 0,34 \\
\hline TOTAL & 1 & & 3,12 \\
\hline
\end{tabular}

Table 6. Value Nilai External Strategic Factors Analysis Summary

\begin{tabular}{|c|c|c|c|}
\hline Internal Strategy Factors & Weight & Rating & $\begin{array}{c}\text { Results } \\
\text { of } \\
\text { Weight } \\
\text { X Rating }\end{array}$ \\
\hline \multicolumn{4}{|c|}{ OPPORTUNITIES } \\
\hline Ketersediaan inovasi teknologi & 0,18 & 1 & 0,18 \\
\hline Ada rekan bisnis & 0,12 & 2,67 & 0,27 \\
\hline Ada petugas penyuluh pertanian & 0,19 & 1 & 0,19 \\
\hline Kebijakan pemerintah yang kuat & 0,19 & 1 & 0,19 \\
\hline \multicolumn{4}{|c|}{ THREATS } \\
\hline Availability of technological innovations & 0,08 & 3,67 & 0,19 \\
\hline There are business partners & 0,13 & 2,33 & 0,28 \\
\hline There are agricultural extension officers & 0,07 & 3,83 & 0,22 \\
\hline Strong government policy & 0,04 & 3,33 & 0,13 \\
\hline $\begin{array}{l}\text { TOTAL } \\
\end{array}$ & 1 & 18,83 & 1,65 \\
\hline
\end{tabular}

\section{CONCLUSION}

The results showed that the amount of acceptance of legowo rows was higher than tiles, amounting to $9,358.3 \mathrm{~kg} / \mathrm{ha}$ or Rp. $15,152,802.25$ for the cropping pattern legowo row and 4,185.4 kg/ha or Rp. 7,101,485, for the receipt of unhulled rice production in the tile cropping pattern, the difference in http://ijstm.inarah.co.id 
production revenue is $5,172.9 \mathrm{~kg} / \mathrm{Ha}$ or $\mathrm{Rp} .23,277,901$ and the $\mathrm{R} / \mathrm{C}$ ratio value of 1.53 legowo rows and 1.49 for tiles.To increase rice farming in Moncongloe District, there are several strategies that can be used, including:

S-O Strategy (Strength-Opportunities)

1. Developing and increasing the capacity of farmers' human resources in agricultural technology innovation (S1, S4, O1, O3). The lack of knowledge of farmers about technological innovations in agriculture will result in no increase in yields in the developed farms. For this reason, it is hoped that the training intensity needs to be increased.

2. Human resource development for lowland land resources in order to get maximum rice productivity ( $\mathrm{S} 1, \mathrm{~S} 2, \mathrm{~S} 3, \mathrm{~S} 4, \mathrm{~S} 5, \mathrm{O} 1,03)$. zWith technological innovation and modern input production tools, it is hoped that rice farming actors can maximize the function and use of these tools for the progress of farming.

3. Synergize between farmers, extension officers, entrepreneurs, and local governments (S1, S2, S3, S4, O2, 03,04). Support from all parties such as the local government, agricultural extension agents, and entrepreneurs is one of the efforts aimed at increasing the farming of lowland rice farmers and one of the strategic factors that can be used to carry out rice farming activities.

\section{W-O Strategy (Weaknesses-Opportunities)}

1. Increase the ability to master appropriate technology for farmers (W1, W2, O1, $\mathrm{O} 2, \mathrm{O} 3, \mathrm{O} 4)$. With the limited human resources owned by farmers in Moncongloe District, it is necessary to carry out training and counseling that can add insight to farmers on how to use technology that can increase the production of lowland rice commodities.

2. Increase farmers' knowledge and insight through field schools and training (W3, O1, O3). One method to increase farmers' knowledge in Moncongloe District is the Paddy Integrated Crop Management Field School (SL-PTT). SLPTT Padi is a national strategic program to support increased production and stabilization of rice self-sufficiency in Indonesia. Field School is an effort to improve the ability of farmers in rice farming.

3. Intensification of environmentally-friendly rice farming ( $\mathrm{W} 3, \mathrm{O} 1, \mathrm{O} 3, \mathrm{O} 4)$. Farmers in Moncongloe District make more use of natural resources around them, especially the use of livestock waste and organic waste for fertilizer.

4. Providing credit loans with low interest with an administrative process that is not too long/short (W3, O2). So far, farmers are reluctant to deal with credit through banks because of the high-interest rates for farmers and the long administrative process. 
S-T Strategy (Strength-Threats)

1. Optimization of agricultural land (S1, S2, S3, S4, T1, T2, T3, T4). According to the Ministry of Agriculture (2019), Optimization of Agricultural Land is an effort to increase the use of land resources that are temporarily not cultivated or low IP to become more productive agricultural land, through physical and chemical improvements to the soil and assistance with other facilities and infrastructure to support the increase in planting areas and/or cropping index (IP). Inland optimization activities, there are several pillars/systems that need to be carried out, namely:

1) Optimization of land and water resources through the management of surface water, groundwater, increasing soil fertility

2) Cultivation of food crops and horticulture diversity is in accordance with the agro-climate zone

3) Plant and livestock integration systems to increase the added value of agricultural and livestock production and increase land productivity

4) A conservation farming system to reduce tillage practices, use of mulch, and cover crops, crop rotation, intercropping using nitrogen-fixing plants

5) Reuse of agricultural and livestock waste in agricultural production systems by making optimal use of agricultural and livestock products

With the five pillars/systems mentioned above, the land optimization activities in the Moncongloe District will give more results. So that the function of the land is less than optimal, it will further increase its function

2. Held Field School on Climate (SLI)

3. Improve the quality of human resources of extension workers and farmers ( $\mathrm{S} 1$, S2, S3, S4, W1 W2, W3)

W-T Strategy (Weaknesses-Threats)

a. Using varieties that are resistant to pest attacks and are able to withstand extreme conditions (T2, T3, W1, W3)

b. Raise awareness of the importance of manure for agricultural land (W3, T2, T3). With the presence of livestock manure waste, it is hoped that farmers in Moncongloe District will optimize the livestock manure waste more.

\section{ACKNOWLEDGMENTS}

The authors are grateful to Program at Postgraduate, and to the Department of Agricultural Socio-Economics. We also thank Team authorfor your good cooperation. Magister Science Agribusiness Study Program - Hasanuddin University Makassar,Department of Animal Husbandry Socio-Economic Sciences - Hasanuddin University Makassar,Management Science Department, Faculty of Economics and Business - Hasanuddin University Makassar. 


\section{REFERENCES}

[1] Luthfiyah. S. 2014. Ilmu Usaha https://ilmuusahatani.wordpress.com/2014/11/19/ilmu-usaha- tani/.

[2] Saeri, M. 2018. Usaha tani dan Analisisnya.Universitas Wisnuwardhana Malang Press (Unidha Press). Malang

[3] Abdulrachman, S., dkk. 2013. Sistem Tanam Legowo. Badan Penelitian dan Pengembangan Pertanian Kementerian Pertanian.

[4] Aji. AA., dkk., 2014. Strategi Pengembangan Agribisnis Komoditas Padi Dalam Meningkatkan etahanan Pangan Kabupaten Jember.Jurnal Manajemen dan Agribisnis, Vol. 11, No. 1, Maret 2014, Https://Media.Neliti.Com/Media/Publications/10856-Id-StrategiPengembanganAgribisnis-Komoditas-Padi-Dalam-MeningkatkanKetahanan-Pan.Pdf

[5] Nisak. Z, 2013.Analisis Swot Untuk Menentukan Strategi Kompetitif.http://docplayer.info/403413-Analisis-swot-untuk-menentukanstrategikompetitif-zuhrotun-nisak.html.

[6] Rangkuti, Freddy, 2015, Analisis SWOT Teknik Membedah Kasus Bisnis,: Penerbit : Gramedia Pustaka Utama.

[7] Sedarmayanti, 2014, Manajemen Strategi, Cetakan kesatu, penerbit : PT. Refika Aditama, Bandung.

[8] Triatmoko. E., dkk., 2018. Perbedaan Usaha tani Padi Sistem Jajar Legowo Dengan Sistem Tegel di Desa Tambak Sarinah Kabupaten Tanah Laut. https://ojs.uniskabjm.ac.id/index.php/ziraah/article/download/1283/1091 